\title{
On Historical Connections in/to Food as Medicine
}

Surfeit, age, and sickenes, are enemies all to health, Medicenes to mende the bodie, excelleth worldly wealth: Physicke shall florishe, and in daunger will give cure, Till death unknit the lively knot, no lenger we indure. --William Bullein, 1584

When Cristina Hanganu-Bresch proposed this special issue on Food as Medicine, we were excited to bring RHM into conversation with a growing emphasis on food and the rhetoric of food. As with all special issue proposals, the editorial board provided feedback and then the final editorial decision to proceed with the issues was made by Blake Scott and me. In this case, we endorsed the board's recommendation because the editorial board praised the topic for its timeliness because of pervasiveness of food and health in popular culture.

I had to smile to myself about the timeliness because food as an integral part of health and medicine has long historical roots. Throughout graduate school (from my master's through my dissertation) and in the early years of my career, I traveled to archives to read old books and manuscripts and learn all about the history of medicine. Most scholarship has focused on those aspects of early modern medicine that "have been progressive and evolutionary to the neglect of the whole range of beliefs, attitudes, and practices which formed the basis of contemporary medicine [...]" (McConchie, 1997, p. 4). One result of this "neglect" is that scholars have failed to fully examine and understand the everyday discourse. And so much of this knowledge was intimately connected to food.

This essay is a complement to the full issue and meant, as the title suggests, to place the idea of food as health and medicine within an historical context. Traces of everyday knowledgemaking and circulation can be found in a wide variety of late medieval texts. Take for example 
the large numbers of letters left behind by the Paston family. In their correspondence, mostly between the years 1422-1509, issues of health and healing are interspersed with discussions of family business and news of days. On September 28, 1443, Margaret writes to her sick husband John that she wishes she was with him so she could care for him during his illness. The letter's postscript offers John medical advice: "be wel dyetyd of mete and dryngke, for that is ye grettest helpe that ye may have now to your helthe ward" (Paston).

Not even the King was immune from health concerns. As Derek Wilson (2002) claimed, Henry VIII constantly worried about his health, even moving court when he heard rumors of disease. And Henry had good reason for his kingly paranoia having come to power because young Prince Arthur contracted the "sweating sickness" and died. The "sweating sickness" was feared in England, and in a letter dated August 19, 1517, Thomas More writes to Erasmus about a recent outbreak:

If ever we were in trouble before, our distress and danger are at their greatest now, with many deaths on all sides and almost everyone in Oxford and Cambridge and London taking to their beds within a few days and the loss of many of my best and most honourable friends; among them (which I am sorry to think will bring you sorrow too) our dear Andrea Ammonio, ... For this sweating-sickness is fatal only on the first day. I and my wife and children are still untouched, and the rest of my house-hold have entirely recovered. But of this I can assure you: one is safer on the battlefield than in the city. (Erasmus)

What these examples illustrate is that medicine, health, and healing were part of early modern society just as they are today. 
I'm going to take you back to an era when print was just beginning in England (ca. 1475) and look at some early "vernacular medical texts," which are books printed in English for a nonmedial readership (Fissell, 1992, p. 72). As George Clark (1964) wrote in his history of the Royal College of Physicians, "[William] Caxton printed this little book [Governayle of Helth] about 1489 and from that time the flow of medicinal books for the household has never ceased [...]" (p. 5). Clark's point still holds true since a simple search of Amazon or the Internet points to thousands and thousands of options on how to stay healthy or to achieve wellness through food.

The vernacular medical texts follow a genealogy from early manuscript culture, which I mean here as the circulation of texts in various forms of letters or oft copied and circulated copies of "learned" texts. The information from manuscripts moved fairly readily into early printed texts, and these early texts take on many forms, and as book historians have shown, the size of a book indicates potential markets and helps potential readers select texts (see e.g., Alcorn, Lindquist, \& Shevlin, 2007; Eisenstein 1973; McKitterick, 2003). A folio was usually a specialized text that was requested by the upper classes and paid for in advance, while octavos, and many quartos are much smaller and were usually printed on speculation because of the likelihood of a quick sale. Figure is an example of an octavo text. 


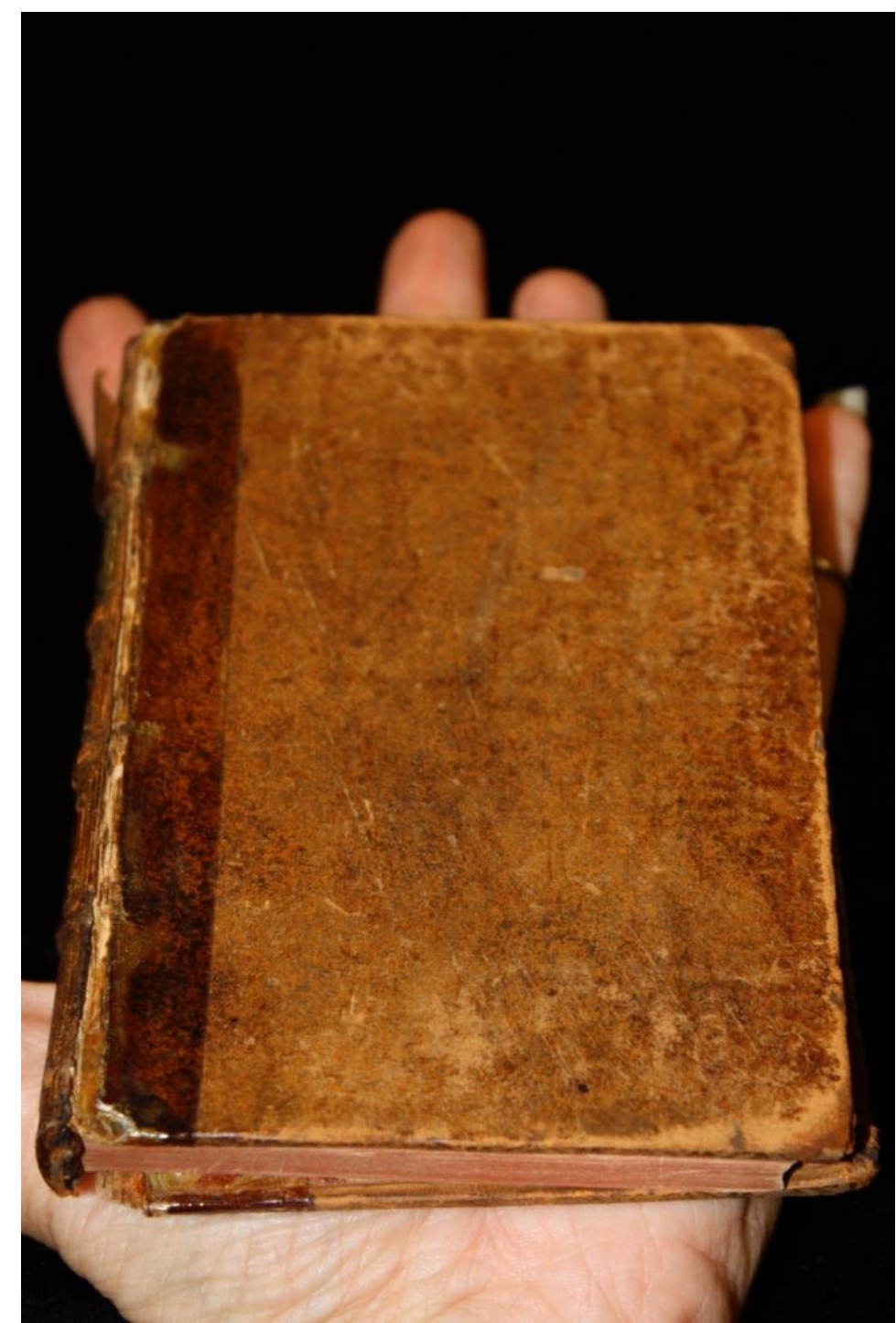

Figure 1: Castel of Health (ca. 1559) by Sir Thomas Elyot in the author's hand for size comparison. University of Cincinnati Rare Books. Photo taken by author.

These cheaply printed books such as the one in Figure 1 were part of a growing marketplace that specialized in quotidian discourse. For well over 150 years, three textual forms dominated the print medical marketplace (Fissell, 2007; Melonçon, 2006; Slack 1979): specific subject books, remedy books, and regimen books. Specific subject books are limited to one subject like plague tracts, uroscopies, or wound care. Remedy books (also known as leech books or recipe/receipt books), as their category title suggests, provided remedies for common ailments. For example, they included topics familiar to a modern reader, such as headaches and toothaches, and they 
also provided remedies for ailments of the early modern era, such as worms in the belly or webbed eyes. The third form, regimen books, explained theories of medicine and provided preventive guidelines of medicine. For example, regimen texts described a humoral theory based on the Hippocratic and Galenic medical corpuses - that is, a body composed of four humors and six non-naturals that must always be kept in balance. These texts also discussed food properties and daily activities that helped to keep and restore balance to the body.

In translating the Italian regimen text Regimen Sanitatis Salerni (ca. 1528) into English, Thomas Paynell explained why he decided to publish his text:

"Redying of olde authors...I fynde/ that men in tyme past were of longer life/ and of more prosperous helthe/ than they are now adayes" (A2r), and he continued, "So what profiteth us a boke/ be hit never so expedient and frutefull/ if we understande hit nat. Wherefore I / consydryng the frute that might come of this boke/ if hit were translated in to the englishe tonge (for why/ every man understandeth nat the latine)" (A3r).

Paynell, like many translators, compilers, and authors of the era, directly addressed the readers to justify and/or explain the reasons for the book. These sorts of rationales and justifications were key components of early modern vernacular medical texts, and these same components came into view because of the close integration of rhetorical theory.

Alongside vernacular medical texts, another "steady seller" (Hall, 1996, p.61) of this era were instructional texts in the arts of rhetoric. Texts such as Leonard Cox's (1532) extolled the principles and practices of rhetoric, and the early rhetoricl tects highlighted the importance of rhetoric in education. Thus, the early authors, translators, and compilers were familiar with the rhetoric as a means for composing and creating texts. As Stephen Pender (2005) argued, "Rhetoric's role in propagandizing medicine and medicine discoveries was clear: changes in 
theory and practice (as well as professional authority) were secured rhetorically and, then as now, rhetoric was an essential component to shifts in styles of investigation and scenes of inquiry" (p. 57) that enable the vernacular medical text to provide historical clues about health and medical beliefs of the era.

The remedies and regimens provide us a glimpse of existing medical ideology as it played out in the homes and daily care of early moderns. Rhetoric as an analytic tool sheds light on the vernacular medical texts' constructed language and the implications of that construction on the making of medicine. Thinking of early modern medicine in these rhetorical terms opens up vernacular medical texts to a complex interpretation and statement on early modern society and helps explain "the relationship of rhetorical events to the material world that sustains and produces" (Selzer \& Crowley, 1999, p. 9). Within this interaction between rhetorical events and the sustaining culture is the primacy of the interaction between text and audience.

For example, each time an early modern needs to understand humoral effects of a certain food, a new rhetorical situation presents itself. Reader, author, and text are then engaged with rhetoric; it can influence people and help them understand "the struggles over what kind of society [they] will live in and what sort of people [they] will be" (Brummett, 1994, p. 4). By restoring rhetoric to its full scope, the vernacular medical texts and their content demonstrate how rhetoric was used to advance both medicine and rhetoric. As Christopher Langton wrote in 1547: "Phisicke is one those artes whyche doth make thinges invented, or found out by reason and experience, and the whyche partly defendeth health, and partly beteth away disease, and sicknes." And this medical ideology was enacted through a sophisticated and consistent deployment of everyday rhetoric. 


\section{The everyday}

Turning to the everyday means acknowledging it is a prime locus for understanding historical and current configurations of food as medicine. What struck me through the production of this special issue is that all of the essays can be tied together by their emphasis on the everyday. While the everyday changes with each entry, they all have an awareness of quotidian and even ephemeral moves to diet, "And by dyete is understande the mynystrynge of meate and drynke," (Regiment, U2r) and what diet means to the person's overall health.

Today if you don't feel well, you first try the home remedies handed down to you from your parents: gargle with salt water if your throat hurts or get more rest. Another option might be to search the Internet to solve your problem or address your concern. And if the symptoms and feelings persist, you make an appointment to see a doctor. Well, imagine yourself transported back 500 years when doctors weren't readily available, or if they were, they were too expensive for most people or not to be trusted. As Bruce Moran (2005) has shown in his study of alchemy, theories of health and medicine can sustain people in their lives even though they lacked scientific evidence of actually working because these texts "followed naturally from an intellectual context that was securely anchored into particular philosophical suppositions, religious beliefs, and social institutions" (p. 25). Thus, the medical marketplace consist of your own traditions, those of your neighbors, maybe a commonplace book with lists of remedies, purgatives, and an astrological tract, and the only other means of care for the vast, new middling sort were vernacular medical texts that circulated an amalgam of knowledges: commonplace, experience, and learned.

Looking at early modern medicine in these terms means exposing the daily medical practice and finding new ways of understanding early modern medicine. The everyday is also 
important as a grounding mechanism for medicine. No matter the effects of technological advancements, those advancements are still considered and used in everyday situations. Vernacular medical texts were one of the earliest forms of health communication, that is, communication specifically created to share health related information with the goal of influencing or engaging individuals to practice specific behaviors to improve health (c.f., Schiavo, 2007, p. 28). They extended into print much of what people-from the yeoman to the housewife to the King - believed about their own bodies, medical practice, and medical theory.

Regimen texts highlight this everydayness and the intimate relationship of food as medicine. Following long traditions out of the East and the West, manuscripts in early modern England extolled the virtues of food for keeping the humors in balance. According to the Hippocratic tradition, the humors, "are the things that make up the body's "constitution and cause it pains and health." English medical theory originates from the Hippocratic corpus (5th century BCE) and extends through Claude Galen (129-201 CE) and Arabic traditions, notably Avicenna (tenth to eleventh century CE) (see Lloyd, 1983). A key component of the success of humoral theory relies on reason and experience. Balance is the foundation of human physiology and relies on the patient or practitioner's ability to understand the body and logically conclude what needs to be done. Basic medicine relied on the concept of the seven naturals. Table 1 illustrates the combinations of the elements (fire, air, water, earth), the qualities (hot, cold, dry, moist), the humors (blood, phlegm, yellow bile, black bile), and corresponding temperaments. Food, drugs, and drink also had humoral properties, which aided in treatments.

Table 1: Humoral Properties

\begin{tabular}{|l|l|l|l|}
\hline Qualities & & Hot & Cold \\
\hline \multirow{2}{*}{ Dry } & humor & Yellow Bile & Black Bile \\
\cline { 2 - 4 } & element & Fire & Earth \\
\hline
\end{tabular}




\begin{tabular}{|l|l|l|l|}
\hline \multirow{3}{*}{ Moist } & temperament & Choleric & Melancholic \\
\cline { 2 - 4 } & humor & Blood & Phlegm \\
\cline { 2 - 4 } & element & Air & Water \\
\cline { 2 - 4 } & temperament & Sanguine & Phlegmatic \\
\hline
\end{tabular}

For example, a disease that was hot and dry could be balanced or cured by substances that were cold and moist. "Health is primarily that state in which these constituent substances are in the correct proportion to each other, both in strength and quantity and are well mixed." (Clark, 1983). For example, a disease that was hot and dry could be balanced or cured by substances that were cold and moist. "Health is primarily that state in which these constituent substances are in the correct proportion to each other, both in strength and quantity and are well mixed." (Clark, 1983) When the humors were out of balance, you were sick. To regain health, the body had to be put back in balance, which occurred through the natural process of purging through enemas, bleeding, or vomiting. The process of purging and bleeding would often be done in relation to the astrological calendar.

The "non-naturals" are another key aspect of humoral theory that influenced health and wellness. The non-naturals existed outside of the body and could affect overall corporeal health. As Thomas Elyot explained, the non-naturals "be soo callyd, bycause they be no porcion of a naturall body, $[. .$.$] yet by temperance of them, the body being in health" (Elyot). The six non-$ naturals are food, drink, and fasting; sleep and wakefulness; air (or the environment); exercise and rest; excretion and retention; and emotions or passions. The non-naturals work in tandem with the humors. For example, one could fast in an attempt to balance after over-indulgence. One could wear a cap to bed to affect air or one could eat more of certain foods to encourage excretion. Hot and cold are not actual temperatures, but instead, are an inherent quality and its effects on the body. 
Therefore, all foods fell into categories that would help someone balance (or rebalance) their humors. Examples of two of the most popular regimen texts of the day are Thomas Elyot's, The Castel of Helth (ca. 1534, hereafter referred to as Castel), published at least 17 times between 1534-1610, and Thomas Paynell's, Regimen Sanitatis Salerni (ca. 1528, hereafter referred to as Regiment), published at least 9 times from 1528 to 1634 . Both the Castel and the Regiment are based on an Italian medical text dating back to the 1300 s.

The regimen texts spend a great deal characterizing different food qualities and properties, along with a brief section on exercise, meal times, and purgation. While the order may be different, the books share common topics and share the same information as their medieval antecedents, which suggested a level of their success in the book-selling marketplace. For example, Table 2 illustrates the characteristics of onions from a medieval manuscript as well as from the Castel and Regiment.

Table 2: Characteristics of onions in regimen texts and a medieval antecedent.

\begin{tabular}{|l|l|l|}
\hline MS X 91 (17a-b) & Castel (D2v-D3r) & Regiment (U3v-U4r) \\
\hline oynones & onyons & oynions \\
\hline $\begin{array}{l}\text { Oynones ben good; but } \\
\text { of hem semeth nat leches } \\
\text { for to/ assent ne accorde } \\
\text { together for Dioscordes } \\
\text { seieth that they bother } \\
\text { the head and greveth it } \\
\text { and make thirsty that } \\
\text { etieth hem rawer./ Galen } \\
\text { seieth that oynones ben } \\
\text { nat good to melancolies } \\
\text { than the rounde, the } \\
\text { redde more than the } \\
\text { white the drye more than } \\
\text { they which he troumatik } \\
\text { they ben right gode. }\end{array}$ & $\begin{array}{l}\text { also rawe more than } \\
\text { sodden: }\end{array}$ & $\begin{array}{l}\text { Fyrste/ touching thyr } \\
\text { operation phisitions } \\
\text { agree nat: for some saye } \\
\text { they be good for } \\
\text { flematicke folks: and } \\
\text { some say naye/... they } \\
\text { they engender } \\
\text { superfluous and } \\
\text { flematyke humours in } \\
\text { the stomake. Secondly/ } \\
\text { Galen saythe/ they be } \\
\text { ryghte hurtfull for } \\
\text { colerike folks... and } \\
\text { wype away fleumatike } \\
\text { and clammy humours / }\end{array}$ \\
\hline
\end{tabular}




\begin{tabular}{|l|l|l|}
\hline & & $\begin{array}{l}\text { growen in the fleumatike } \\
\text { folks.... }\end{array}$ \\
\hline $\begin{array}{l}\text { Asclepinus seieth that } \\
\text { they ben goode and } \\
\text { namely to the stomak... } \\
\text { maken hem faire } \\
\text { colored/ that lokyn up-on } \\
\text { hem... wole hele } \\
\text { houndes } \\
\text { bytinges...grounde } \\
\text { smalle thou might restore } \\
\text { the here of the hede... }\end{array}$ & $\begin{array}{l}\text { They styrre appetite to } \\
\text { meate, and pute awaye } \\
\text { lethsomnesse, and lowse } \\
\text { the bealy, they quicken } \\
\text { syght: and beynge eaten } \\
\text { in great abundance with } \\
\text { meate, they cause one to } \\
\text { sleape soundly } \\
\text { they make a man well } \\
\text { colered:... restore heares } \\
\text { agayne/...For a farther } \\
\text { knowledge of onyions } \\
\text { operation/witteth/that } \\
\text { they stere to carnell } \\
\text { luste/ stoke the appetite/ } \\
\text { brynge colour in the } \\
\text { face/... they engender an } \\
\text { ill gross humour they } \\
\text { entreate spittell/.... } \\
\text { Farther note/... good for } \\
\text { bytynge of madde } \\
\text { dogge. }\end{array}$ \\
\hline
\end{tabular}

In Table 2, the texts and their medieval antecedent discuss the qualities of onions. The manuscript from the 1400s and the Castel both refer to its properties of being hot and dry and the degree to which it is hot and dry, while Regiment in not as specific. All three texts agree that fennel is a good curative for stomach distress. The manuscript antecedent and Regiment also indicate that fennel is good for the "eyen" and "syght," which was a major concern for early moderns. Either the original sources disagreed or Elyot and Paynell chose to include different information in their texts since Paynell's list more values for fennel than Elyot.

\begin{tabular}{|l|l|l|}
\hline Med. Society 136 (221) & Castel (D5v) & Regiment (E4r) \\
\hline Pepper & Pepper & Pepper \\
\hline $\begin{array}{l}\text { For there are three } \\
\text { manners of pepor ther is } \\
\text { blak pepper that is clepid } \\
\text { melan pepyre and there } \\
\begin{array}{l}\text { is white pepper and } \\
\text { longe pepper ... }\end{array}\end{array}$ & $\begin{array}{l}\text { Blacke pepper is hottest, } \\
\text { and moste drye, whyte } \\
\text { pepper is next, longe } \\
\text { pepper is most } \\
\text { temperate. }\end{array}$ & $\begin{array}{l}\text { There be .iii. sortes of } \\
\text { pepper white } \\
\text { pepper/...longe } \\
\text { pepper/...\& black } \\
\text { pepper }\end{array}$ \\
\hline $\begin{array}{l}\text { But the blake pepper is } \\
\text { most of vertu and most }\end{array}$ & $\begin{array}{l}\text { The general propertye of } \\
\text { all kyndes of pepper is }\end{array}$ & $\begin{array}{l}\text { blacke pepper/ through } \\
\text { hit heate \& brines/ }\end{array}$ \\
\hline
\end{tabular}




\begin{tabular}{|l|l|l|}
\hline $\begin{array}{l}\text { used but pepper is not } \\
\text { gode for coleryke men } \\
\text { for sangwyn men but it } \\
\text { be the lesse [good] }\end{array}$ & $\begin{array}{l}\text { to heate the bodye, but } \\
\text { as Galen sayeth, it } \\
\text { perceth downeward, and } \\
\text { doth not spread into the } \\
\text { vayne, yf it be grosse } \\
\text { beaten. It dissolueth } \\
\text { fleume and wynde, it } \\
\text { helpethe digestion, } \\
\text { expulseth urine, and it } \\
\text { helpeth against the } \\
\text { diseases of the breaste, } \\
\text { procedynge of colde...It } \\
\text { is hot in the fyrst degree, } \\
\text { \& dry in the second. }\end{array}$ & $\begin{array}{l}\text { leveth quickely" for it is } \\
\text { hotte and drie in the .iii. } \\
\text { degree. ...hit purgeth } \\
\text { fleme...it helpeth } \\
\text { digestion. And this } \\
\text { appereth by Avicen/ } \\
\text { sayeth: that pepper is } \\
\text { digestive causing } \\
\text { appetite...whyte pepper } \\
\text { comforteth the } \\
\text { stomake....pepper heteth } \\
\text { the senowes and braunes } \\
\text { of mans body...and a } \\
\text { lyttell thereof provoketh } \\
\text { the urine... }\end{array}$ \\
$\begin{array}{l}\text { Virtues of } \\
\text { pepper in } \\
\text { and in a } \\
\text { medieval } \\
\text { antecedent. }\end{array}$ \\
\hline \\
& $\begin{array}{l}\text { Table 3: } \\
\text { [contained in text: Galen } \\
\text { sayeth] }\end{array}$ & $\begin{array}{l}\text { [contained in text: } \\
\text { Avicen sayeth] }\end{array}$ \\
\hline
\end{tabular}

Table 3 describes the characteristics of pepper. Regiment and Castel vary widely from the manuscript version, but the three texts do agree on the kinds of pepper and the idea that peppers have positive medical qualities. The manuscript is quite brief in its description and only references that pepper is not good for those with choleric or sanguine temperaments. The printed texts are more descriptive in their properties and values, and they do have common agreement that pepper helps with invoking urine and soothing the digestion and/or stomach. The different interpretation of sources illustrates simultaneously the variety of medical resources early modern authors had available to them and the variety of ways those sources could be interpreted. For example, much like the disagreement over pepper, Elyot and Pyanell also did not agree on fish. It appears that Elyot is not a fan of fish as he writes, "all kyndes of fysshe ,aketh more thinner bloudde...so that it doth not moche nouryshe" (Castel, D5v) while Paynell describes a series of ten fish and ends with the fact that they are "very holsome for mans body" (Regiment P1r-v). 
These disagreements are not very different from popular arguments common today about the virtues or harms of certain foods.

Table 4 focuses solely on the regiment texts and their description of peas. Both texts discuss the good and bad qualities of peas. Although the authors use different language, they state that peas can be eaten without the husks.

Table 4: Comparison of description of peas in regimen texts.

\begin{tabular}{|l|l|}
\hline Castel (Dv-D2r) & Regiment (Qv-Q2r) \\
\hline Peasyn & that peasen \\
\hline $\begin{array}{l}\text { Are moche of the nature of } \\
\text { beanes, but they be lasse windy, } \\
\text { and passeth faster out of the body: } \\
\text { they be also abstersyve, or } \\
\text { denying, specially white peason, } \\
\text { and they also cause merely } \\
\text { nouryshynge, the huskes taken } \\
\text { awaye. }\end{array}$ & $\begin{array}{l}\text { some way be holsome/ and some } \\
\text { way unholsome. They be } \\
\text { holsome to eate whan the huskes } \\
\text { be teken away, for if they be } \\
\text { eaten in the huskes/ they enflate. } \\
{[\ldots] \text { but the broth of them is }} \\
\text { holsome. }\end{array}$ \\
\hline $\begin{array}{l}\text { And the brothe wherin they be } \\
\text { sodden clenseth ryghte well the } \\
\text { raynes and bladder. }\end{array}$ & $\begin{array}{l}\text { For the broth maketh the bealye } \\
\text { laxative/ and maketh one pysse/ } \\
\text { and unstoppeth the veynes. }\end{array}$ \\
\hline
\end{tabular}

Both also reference the amount of gas a person can expect; for Elyot peas are "lasse windy" than beans and for Paynell, peas with the husks “enflate." These claims maintain similarity of content, even though they approach their descriptions differently, because the less gaseous properties of peas are apparently very important to the people of the early modern era. The authors include a reference to the broth made from peas because the broth helps the body maintain its balance in two important ways: clearing the bladder/making one urinate and unstopping the veins/“raynes."

Further, the regimen texts emphasis on ideal foods provided additional value to the reader. The high praise for 'eggs somatic effect signals another important facet of the value of the texts. The authors, functioning as experts, put all sorts of meat to the rigorous test of 
nourishment. Eggs seemed to be, based on references in other texts as well, the ideal since they were "animal in prior form" (Albala, 2002, p. 76). Following are Paynell and Elyot's passages concerning the value of eggs as "nourishing meat."

\begin{tabular}{|c|c|}
\hline Castel (E1r-v) & Regiment $(\mathrm{F} 3 \mathrm{r}-\mathrm{v})$ \\
\hline Eges & that peasen \\
\hline $\begin{array}{l}\text { Eges of fesantes, hennes, and } \\
\text { partriches be of all other meates } \\
\text { most agreeable unto nature, } \\
\text { specially yf they be new layde: yf } \\
\text { they be reere, they do clense the } \\
\text { throte and the breaste. If they be } \\
\text { harde, they do flowe in digestion: } \\
\text { but beynge once digested, they do } \\
\text { nouryshe moche. Mean between } \\
\text { rere and hard, they dygeste } \\
\text { conveniently, and noursyhe } \\
\text { quyckely. Egges well poched, ar } \\
\text { better than rosted. If they be } \\
\text { fryed harde, they be of yll } \\
\text { nouryshement, \& do make } \\
\text { stynkyng fumes in the stomake, } \& \\
\text { do corrupt other meates with } \\
\text { whom they be mingled. They be } \\
\text { most holsome, whan they be } \\
\text { poched, and most unholsome } \\
\text { whan they be fryed. [...]( }\end{array}$ & $\begin{array}{l}\text { The fyrste [nourishing meat] is } \\
\text { newe layde egges/ whiche be of } \\
\text { that sorte of foodes that in a little } \\
\text { quantite nouryshe moche [...] } \\
\text { Touchynge the choice of egges/ } \\
\text { wytteth well that the egges of } \\
\text { hennes/ pertriches/ and of } \\
\text { fecances yonge and fatte are very } \\
\text { good in the regiment of helthe/ } \\
\text { and simply/ better than any other } \\
\text { egges: [...] Farther/ poched egges } \\
\text { are better than egges rosted hard } \\
\text { or rere/ and they be of great } \\
\text { nourishement/ and of good and } \\
\text { light digestion/ and they engender } \\
\text { bloudde specyallye } \\
\text { proportyonable to the harte: } \\
\text { wherefore they be exceedinge } \\
\text { good for such as recovered from } \\
\text { sycknesse/ for aged folk/ and for } \\
\text { weake parsons/ and speciallye the } \\
\text { yolke. }\end{array}$ \\
\hline
\end{tabular}

As noted in the examples above, Elyot and Paynell agree on the benefits of eggs and discuss the properties and justification of their use. Elyot and Paynell extol the virtues of eggs by telling their readers that the best eggs come from hens, pheasants, and partridge, and that "new layde" eggs are "most agreeable" and "nouryshe moche." In addition, both authors reference poached eggs. Elyot says poached eggs are "most holsome," while Paynell calls them better since they bring "great nourishement." Not only do they discuss the benefits of eggs' nourishment, they write how the properties of eggs help keep the body in balance: Poached eggs "digest 
conveniently" or are "of good and light digestion." The references to digestion link directly back to humoral theory and the concept of food effecting how the body works. Paynell provides specific times when eggs should be used to help restore the body's health: "for such as recovered from sycknesse/ for aged folk/ and for weake parsons." While Elyot gives a specific use for "cleans[ing] the throte and the breaste." By connecting an ideal food to humoral theory, the authors emphasize the value of the text's content to the reader specifically in relation to their own knowledge of the everyday.

The success of the regimen texts in the book buying marketplace highlights an important aspect of medical knowledge of the era. "Concepts of a unique corpus of established, academic knowledge on one hand, and of backward, simple folk medicine on the other, are equally misleading $[\ldots]$ the two merged together into a largely amorphous whole" (Nagy, 1988, p. 53). The merging of learned and vernacular medicine together illustrates that the remedies, cures, and advice found in early modern manuscript and printed texts existed as part of a common intellectual currency that included basic understanding of humoral theory, uroscopy diagnostics, herbal pharmacology, and astrology, as well as a heavy dose of philosophical advice and reliance on spirituality. The regimen texts specifically became a kind of tool in trying to maintain a healthy diet. Broad scientific knowledge, especially from a modern perspective, aims for generalized conclusions that can be applied to a variety of people. That said, Early modern vernacular texts provided generalized ideas, but not generalized conclusions.

Vernacular medical texts, such as the regimens, clearly helped shape the very idea of what medicine meant, how it was practiced, and how it circulated during the days of the $16^{\text {th }}$ century. Medicine is largely based on the narratives of patients and practitioners, but it is often difficult to recover these voices. However, the vernacular medical texts tell their own, and 
important, story of early modern medicine. They confirm and reaffirm the existing ideological interpretations of theories of medical practice. Vernacular medical texts represent a paradigmatic system of medicine. In enabling vernacular medicine to be widespread and dispersed, they forced "real" medicine to advance new learned theories to supplement the vernacular knowledge. As a paradigmatic system, vernacular medical texts set the standard until the Royal College managed to assert control and wrest authority away from the everyday to an authorized entity controlled by medical practitioners.

\section{Old is New Again}

History of medicine is a palimpsest. New overwrites old, but the history is still present as it is woven into modern culture with threads that can no doubt be traced through time. The essays in this special issue are an historical marker in a long tradition. Outside of the historical connections between food and medicine, much recent scholarship in RHM connects to issues of the everyday and examines everyday language of health and medicine from a complex rhetorical perspective. As RHM continues to grow and mature, there is a comfort in the historical connections, in the ongoing palimpsest of knowledge that weaves together through time.

On a trip home to Texas several years ago, my father excitedly handed me a cookbook. An important and integral part of a Cajun culture is food, and the cookbook that brought so much joy to my father was written by a cousin who was trying to chronicle the "old ways" of Cajun cuisine. My father told me to be certain to look at the recipe for bread, since it was exactly like his "mama used to make." While I was flipping through the book to get to the bread recipe, I noticed little bits of advice filled the bottom of many pages, and much of this advice centered on medicinal recipes. One in particular caught my eye. To "cure" the common cold, it recommended wrapping your feet in bacon and place a hot water bottle on top. This "cure" can 
also be found in a number of manuscripts circulating in the later $15^{\text {th }}$ century and in early modern vernacular medical texts. Rather than wrapping your feet in bacon, the early moderns recommended smearing the bottom of your feet with the lard of a young pig and then laying down with your feet close to the fire. And the use of bacon and pig lard is aptly connected to regimen traditions since both Paynell and Elyot agreed that pork was a "good, holsome meate."

The importance of examining the history of vernacular medical texts is that they are an excellent example of rhetorical diversity necessary to achieve medical literacy within the context of medicine's nascent institutionalization. The acceptance and widespread use of the regimens (and others) stabilized an unstable medical field and enabled it to move toward its establishment as a scientific discipline. And much of this medical literacy started with an understanding of food as medicine and how food interacted with a person's body and their environment. The vernacular medical texts such as the ones discussed in this short essay blurred the boundaries between everyday knowledge and the learned knowledge of the day; they set up an historical precedent for how we consider the everydayness of health and medicine.

The ongoing emphasis on the healing properties of food some 600 years apart brings us back to the everydayness of where food is an integral part of health and medicine. This, too, encourages scholars to consider timeless questions along a continuum, such as:

- What is the power of everyday medicine in the lives of people who are suffering or who are sick?

- What motivates people to believe in what, on the surface, appears to be an unbelievable home remedy?

- Where are the lines when it comes to what is considered medicine? In what ways are everyday medicines authenticated and codified in different cultural milieus? 
Thinking historically about the everydayness of health and medicine, particularly as seen through the lens of food, reminds scholars that we should not lose sight of important questions about what counts as knowledge and who is allowed and recognized to contribute to that knowledge.

\section{Recent changes at RHM}

As we wrote recently (see editor introductions in 3.3 and 4.1 ), we have begun the process of starting the hand-off of the journal to new co-editors. This year, 2021, marks five years that Blake Scott and I have been at the helm, and our commitment to the community was always for

five years. We will announce a new co-editor soon and formally introduce the new editorial team in issue 4.3 of this year. In the meantime, however, we do want to announce some changes related to our Assistant Editors. We want to thank Ellie Browning for serving three years as one of our inaugural assistant editors. Hearty thank you's go out to Ellie. Joining the team of Assistant Editors are:

- Dr. Bryna Siegel-Finer, Professor, Indiana University of Pennsylvania, joins us as Managing Assistant Editor

- Dr. Fernando Sánchez, Associate Professor, University of St. Thomas, joins us as Assistant to the Editors

- Dr. Molly Kessler, Assistant Professor, University of Minnesota, joins us as Content Strategist; and

- Dr. Erin Trauth, Assistant Professor, High Point University, will remain on the Assistant Editor's team, but in the new role as Special Marketing Content Creator. They will serve three-years terms from 2021 to 2023. 


\section{References}

Albala, Ken. (2002). Eating right in the Renaissance. University of California Press.

Alcorn, Sabrina. B., Lindquist, Eric N., \& Shevlin, Eleanor. (Eds). (2007). Agent of change:

Print culture after Elizabeth Eisenstein. University of Massachusetts Press, 2007.

Brummett, Barry. (1994). Rhetoric in popular culture. St. Martin’s Press.

Clark, Sir George. (1964). The history of the Royal College of Physicians of London, volume 1. Clarendon Press.

Eisenstein, Elizabeth. (1979). The printing press as an agent of change: Communications and cultural transformations in Early-Modern Europe. Cambridge and New York: Cambridge University Press.

Fissell, Mary. E. (1992). Readers, texts, and contexts: vernacular medical works in early modern England. In Roy Porter (Ed.), The popularization of medicine 1650-1850 (pp. 72-96). Routledge.

Fissell, Mary. E. (2007). The marketplace of print. In Mark S. R. Jenner \& Patrick Wallis (Eds.), Medicine and the market in England and its colonies c. 1450-c. 1850 (pp. 108-132). Palgrave

Hall, David, (1996). Cultures of print: Essays in the history of the book. University of Massachusetts Press.

Lloyd, Geoffrey E. R. (Ed.) (1983). Hippocratic writings. Penguin Books.

McConchie, Ronald. W. (1997). Lexicography and Physicke The Record of Sixteenth-Century English Medical Terminology. Clarendon Press.

McKitterick, David. (2003). Print, manuscript and the search for order 1450-1830. Cambridge University Press. 
Melonçon, Lisa. (2006, November). Rhetorical bodies. Paper presented at the Folger Shakespeare Colloquium Vernacular Health and Healing, Washington DC.

Moran, Bruce T. (2005). Distilling knowledge alchemy chemistry and the Scientific Revolution. Harvard University Press.

Pender, Stephen. (2005). Between medicine and rhetoric. Early Science and Medicine, 10(1), 3664.

Schiavo, Renata. (2007). Health communication from theory to practice. John Wiley and Sons.

Selzer, Jack \& Crowley, Sharon (Eds.). (1999). Rhetorical Bodies. University of Wisconsin Press.

Slack, Paul. (1979). Mirrors of health and treasures of poor men: the uses of vernacular medical literature of Tudor England. In Charles Webster (Ed.), Health, medicine and mortality in the sixteenth century (pp. 237-273). Cambridge University Press.

Wilson, Derek A. (2002). In the lion's court: power, ambition, and sudden death in the reign of Henry VIII. St. Martin's Press.

\section{Primary Source References}

Bullein, William. (1562). Bulleins bulwarke of defe[n]ce againste all sicknes, sornes, and woundes, that dooe daily assaulte mankinde, whiche bulwarke is kepte with Hillarius the gardiner, Health the phisician, with their chyrurgian, to helpe the wounded soldiors. Gathered and practised fro[m] the moste worthie learned, bothe old and newe: to the greate comforte of mankinde: doen by Williyam Bulleyn. Imprinted at London : By Ihon Kyngston. STC: 4033. 
Caxton, William. (1490?). In this tretyse that is cleped Gouernayle of helthe what is to be sayd wyth crystis helpe of some thynges that longen to bodily helthe. Westminster : William Caxton. STC 12138.

Cox, Leonard. (1532). The art or crafte of rhetoryke. Imprinted at London : In Fletestrete by saynt Dunstones chyrche, at the sygne of the George, by me Robert Redman. STC 5947.

Elyot, Thomas. (1539). The castel of helth gathered and made by Syr Thomas Elyot knyghte, out of the chiefe authors of physyke, wherby euery manne may knowe the state of his owne body, the preseruatio[n] of helthe, and how to instructe welle his physytion in syckenes that he be not deceyued. Londini : In aedibus Thomae Bertheleti typis impress. STC: 7643.

Erasmus. (1979). The Correspondence of Erasmus Letters 594-841 (1517-1518), vol. 5, trans. R. A. B. Mynors and D. F. S. Thompson. Toronto University Press, letter 623.

Langton, Christopher. (1547). A uery brefe treatise, ordrely declaring the pri[n]cipal partes of phisick that is to saye: thynges natural. Thynges not naturall. Thynges agaynst nature.

Medical Society of London MS 136. (1934). A leechbook or collection of medical recipes of the fifteenth Century, Ed. Warren R. Dawson. London: St. Martins.

Paston family. Paston letters and papers of the fifteenth century, Part I, Electronic Text Center, University of Virginia Library. Letter 126. https://quod.lib.umich.edu/c/cme/Paston

Paynell, Thomas. (1528). Regimen sanitatis Salerni this boke techyng al people to gouerne them in helthe, is translated out of the Latyne tonge in to englishe by Thomas Paynell. whiche boke is as profitable [et] as nedefull to be had and redde as any can be to obserue 
corporall helthe. Imprinted at London : In fletestrete, in the house of Thomas Berthelet. STC: 21596. 